\title{
Why the Big Rise in Business Loans at Banks Last Year?
}

\author{
R. Alton Gilbert and Mack Ott
}

(1) sharply in the first half of 1984, after changing little in the first year of the economic recovery from the 198182 recession. Many analysts of business and financial data cite the rate of growth of business loans at large commercial banks as an indicator of the pace of economic activity. Given that interpretation this pattern of business loans would have signaled a sharp acceleration in economic activity in the first half of 1984. Some analysts offer the altemative explanation for the rapid rise in business loans that bank credit was being used on an unusually large scale to finance corporate mergers and leveraged buyouts." This article investigates the empirical support for these alternative explanations.

R. Alton Gibert is an assistant vice president and Mack Ott is a senior economist at the Federal Reserve Bank of St. Louis. Paul G. Chris. topher provided research assistance.

1See Berry (1984), Heinemann (1984), Jasinowski (1984) and Weiner (1984). In particular, Weiner recounts a barker as emphasizing that

...loan demand has been real....t is being used to finance inventory, plants and equipment w- not mergers and acquisitions...

2See Giordano (1984). Economist Henry Kauman is quoted by Business Week as crediting merger finance for the bulge in loans (see "Do Mega-Mergers..." (1984)):

"Much of the recent credit growth was associated with the merger pheromenon." He says that merger activity explains why first-quarter bus:ness loans at large commercial banks showed an increase of $\$ 4.6$ billion rather than a decline, as they generally do at this stage of the business cycle.

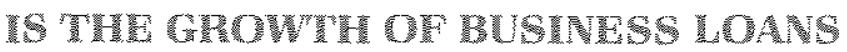

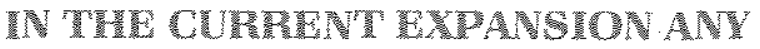

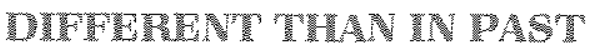 WXPANSIONS?}

The first step in analyzing the relationship between the pace of economic activity and the growth of business loans is to examine the pattern of business loans in the current expansion relative to the patterns in previous expansions. If the pattern of business loans in the current recovery is typical of the pattern in prior expansions, alternative explanations such as bank financing of mergers and buyouts are unnecessary.

Business loans by large (weekly reporting) banks tend to stay at about the same level as at the recession trough during the first year of a recovery period, with this sluggish loan behavior giving way to moderate growth in the second year (chart 1). Thus, for the first year of the economic expansion following the 1981-82 recession, the pattern of growth in business loans by large commercial banks was similar to the pattern of business expansions since 1960.

The growth of business loans at large banks in the first half of 1984, however, was unusually rapid for that stage of an economic expansion. By the spring of 1984, the level of business loans, relative to their level at the trough of the preceding recession, was substantially above the average profile during previous expansion 
Chart 1

\section{Business Loans at Large Commercial Banks Relative to Levels at Recession Troughs}

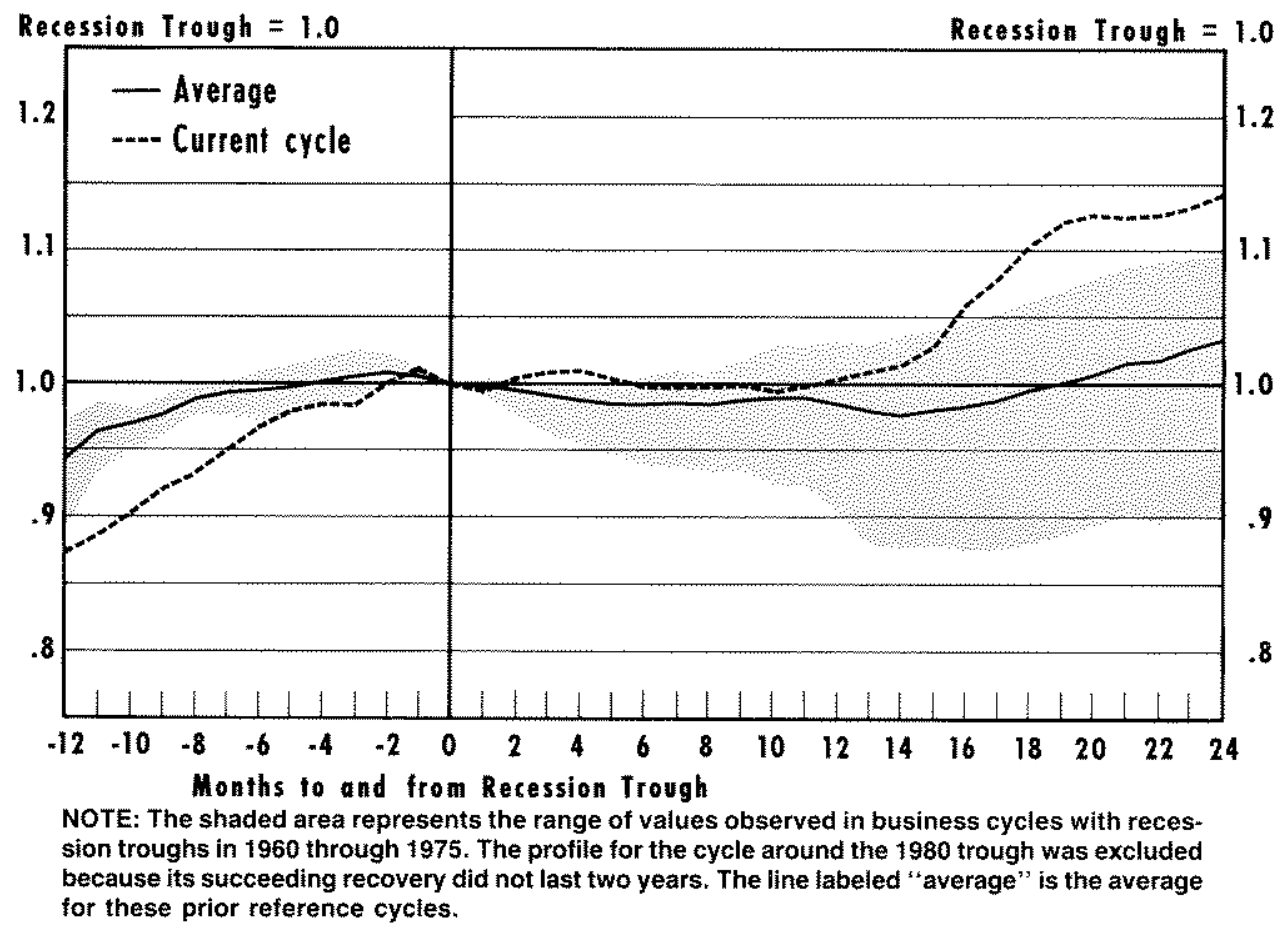

Char: 2

\section{Cycles in Nominal GNP}

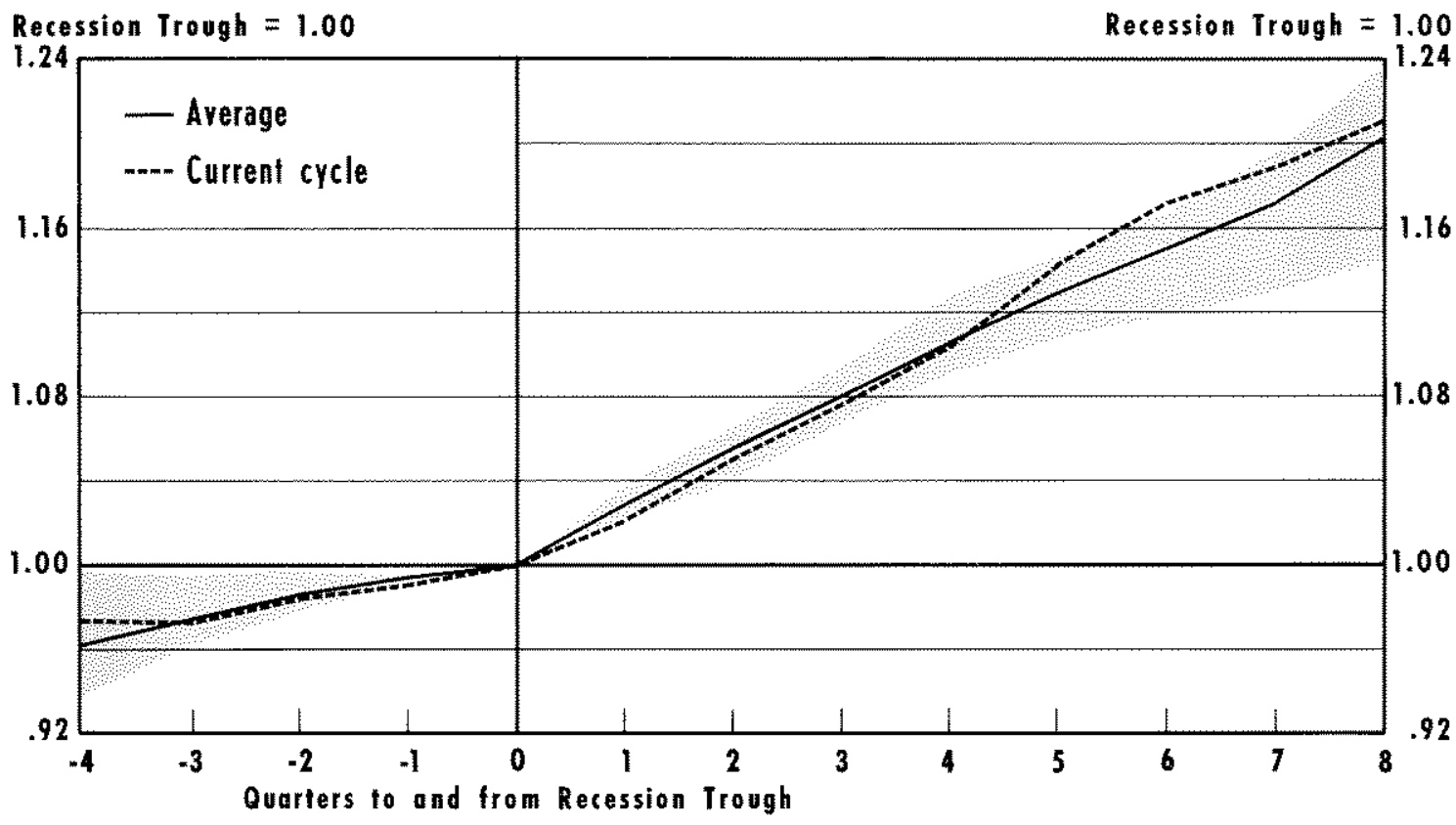

NOTE: The shaded area represents the range of values observed in business cycles with recession troughs in 1960 through 1975. The profile for the cycle around the 1980 trough was excluded because its succeeding recovery did not last two years. The line labeted "average" is the average for these prior feference cycles. 
Chort 3

\section{Cycles in Nonfarm Business Inventories}

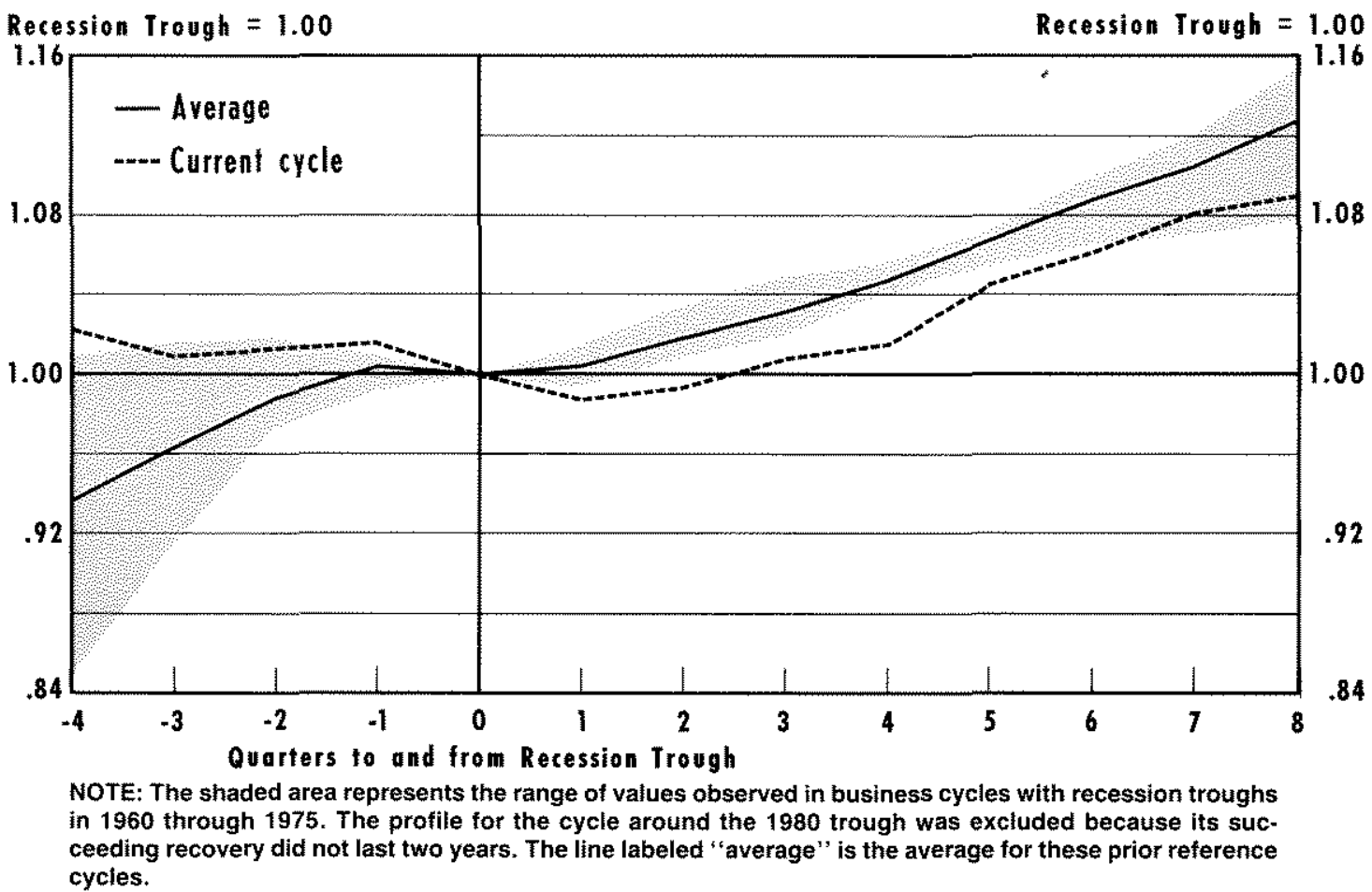

periods. Following their rapid run-up during the first half of 1984, the growth rate of business loans at large banks has been close to the average growth rate during comparable periods of expansion. This can be seen by the parallel movement of business loans since the first half of 1984 and that of the cycle average. Consequently, the only aspect of the growth in business loans by large commercial banks that distinguishes the current expansion is the rapid growth in the first half of 1984 .

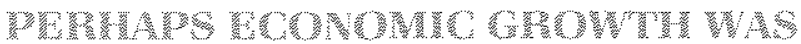

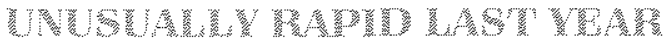

This unusually rapid tise in business loans in the first half of 1984 might reflect simply an unusually rapid rise in the pace of economic activity. This possibility is investigated in chart 2 , which presents nominal GNP for several quarters before and after recession troughs in ratio to nominal GNP in trough quarters. If the pace of economic activity had become unusually rapid by the first half of 1984 , the ratio in chart 2 for the current expansion would be substantially above the range for previous expansion periods. Yet, while the chart shows that nominal GNP did rise to the top of the range for previous reference cycles during the first half of 1984 , it did not rise substantially above the range of experience in prior expansion periods.

An important link between the pace of economic activity and the growth of business loans involves the growth of business inventories. Business inventories tend to rise with the pace of economic activity during expansion periods, and businesses commonly finance their inventory investment through bank loans. "Thus, the unusually rapid growth of business loans last year might reflect an unusually rapid growth of business inventories. Chart 3, however, indicates that the growth of business inventories has not been unusually rapid in the current expansion. In fact, inventory expansion has been slower in this recovery than in any recovery of the past 25 years.

ISee Hicks (1980). 
Chart 4

\section{Ratio of Fixed Plus Inventory Investment to Internal Funds}

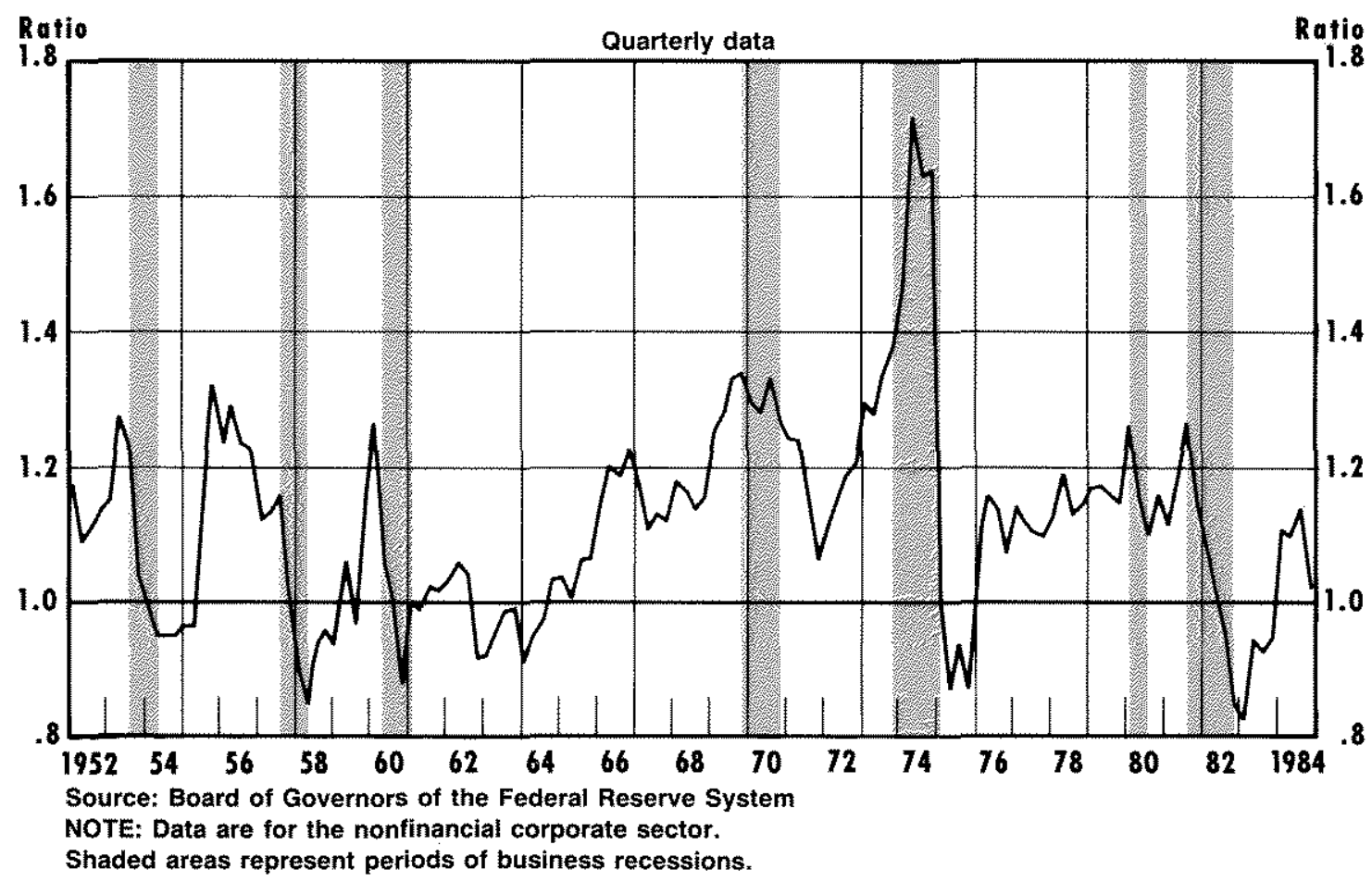

Chart 4 provides an additional perspective on the rise in the demand for credit by businesses in the current and previous expansions. This chart plots the ratio of the fixed and inventory investment of non financial business corponations to their internally generated funds. Nonfinancial corporations require external financing of their fixed and inventory investment whenever this ratio is above unity, but internally gen erated funds substitute for external financing whenever this ratio is below unity.

As illustrated in chart 4, internally generated funds tend to rise more rapidly than business investment during the early stages of economic expansions, so that the ratio is below unity. After a few quarters of expansion, business investment begins to exceed internal funds, and businesses then must turn to external financing. The relationship between intemally generated funds and business investment is one of the reasons for the typical lag in the growth of business loans after the beginning of economic expansions illustrated in chart 1 . Chart 4 clearly indicates that the relationship between business investment and inter- nal funds in the current expansion is typical of prior expansions. Thus, chart 4 provides no explanation for the unusual rise in business loans in the first half of 1984 .

Finally, consider the contrast between the pattern of business loans at large and small commercial banks in the cument recovery. If business loans at large banks reflect the influence of the pace of economic activity on business credit demand, these effects would tend to be similar for both large and small banks. Chart 5 indicates, however, that the pattern of business loans at small banks in the current expansion is very similar to the patterns in previous expansions. Thus, the influences that contributed to the unusually rapid growth of business loans at large commercial banks in the first half of 1984 did not have similar effects in boosting the growth of business loans at small banks.

\footnotetext{
${ }^{4}$ The series on business loans of small commercial banks was calculated by subtracting business loans of weekly reporting banks from a series on business loans of all commercial banks.
} 


\section{Chart 5}

\section{Business Loans at Small Commercial Banks Relative to Levels at Recession Troughs}

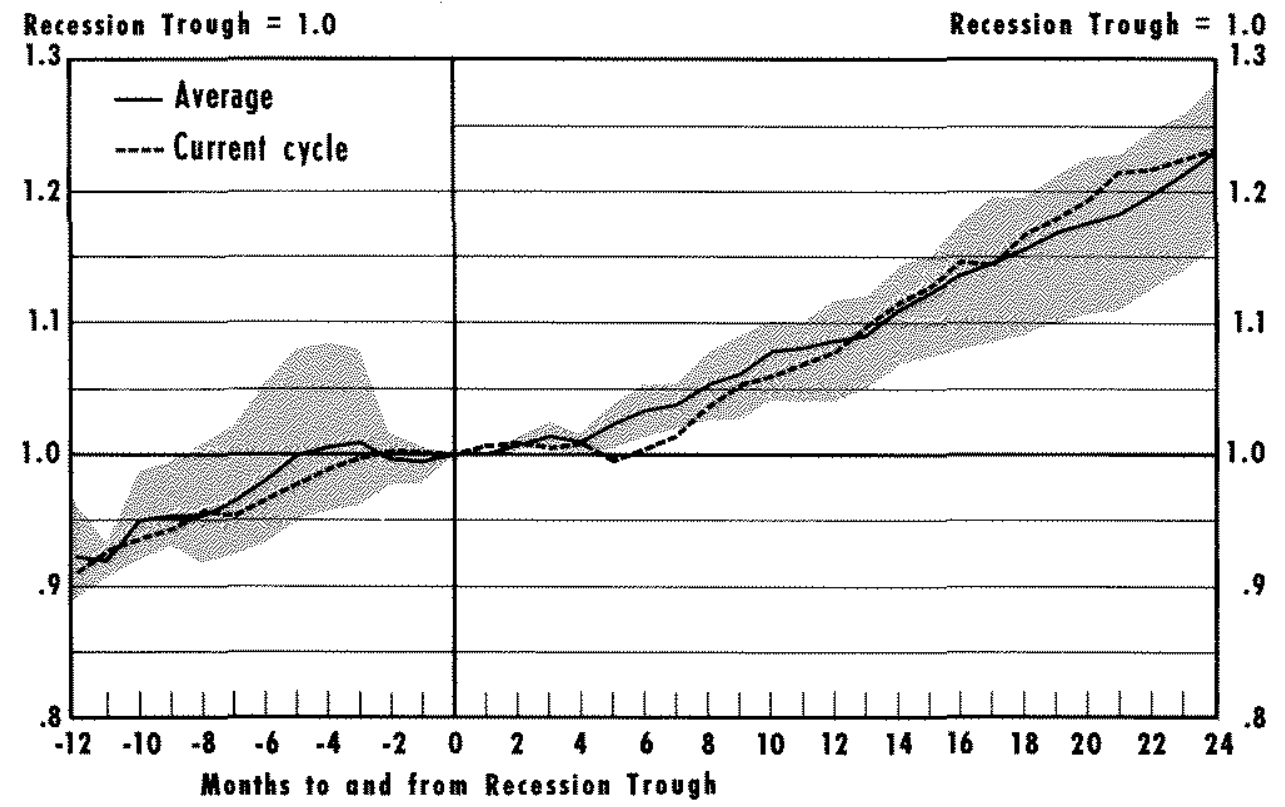

NOTE: The shaded area represents the range of values observed in business cycles with recession troughs in 1960 through 1975. The profile for the cycle around the 1980 trough was excluded because its succeeding recovery did not last two years. The line labeled "average" is the average for these prior reference cycles.

\section{Chari 6}

\section{Cycles in Nonfinancial Commercial Paper}

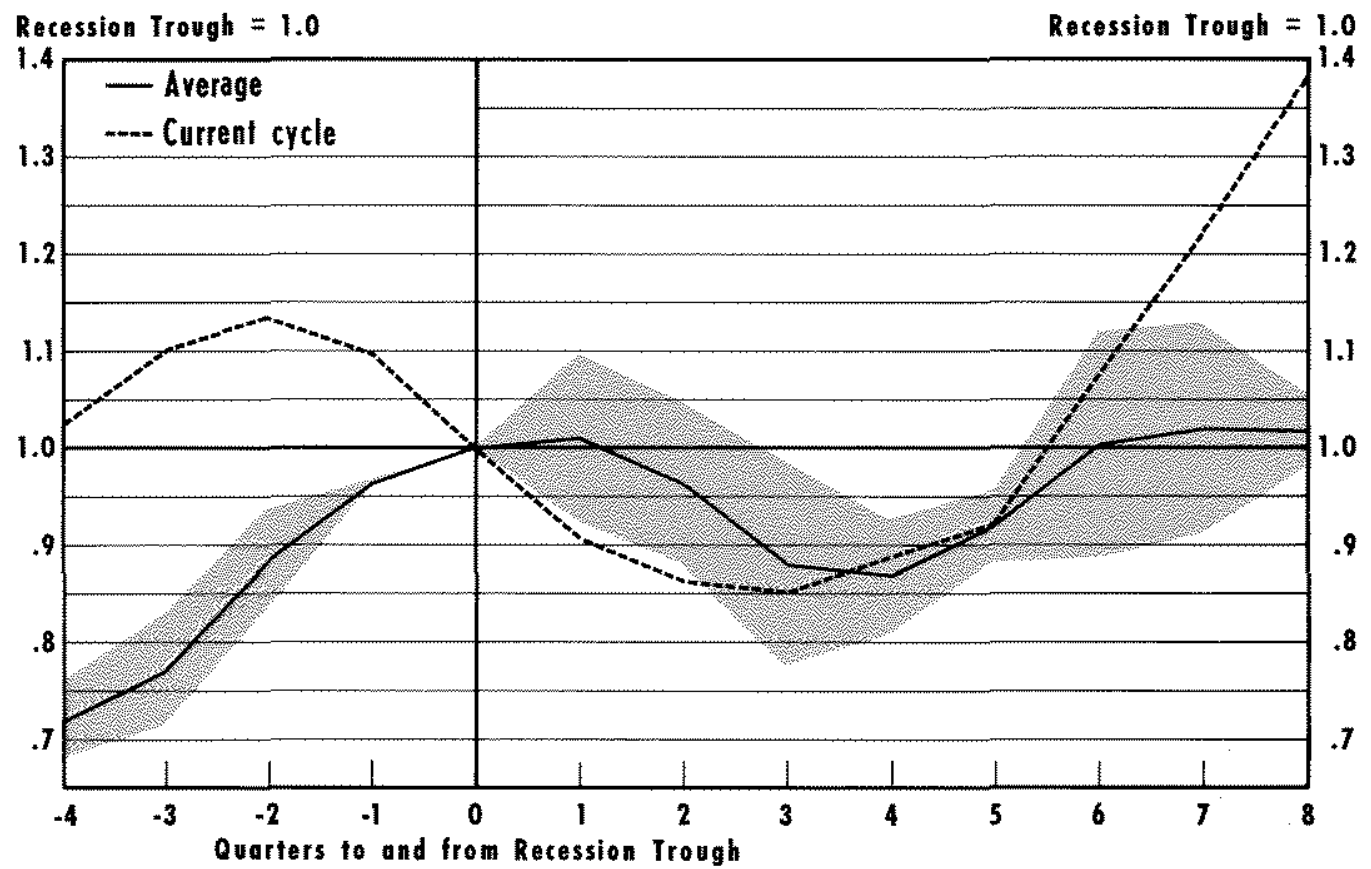

NOTE: The shaded area represents the range of values observed in business cycles with recession troughs in 1960 through 1975 . The protile for the cycle around the 1980 trough was excluded because its succeeding recovery did not last two years. The line labeled "average" is the average for these prior reference cycles. 


\section{Chart 7}

\section{Ratio of Funds Raised by Long-Term Borrowing to Total Funds Raised by Borrowing ${ }^{4}$}

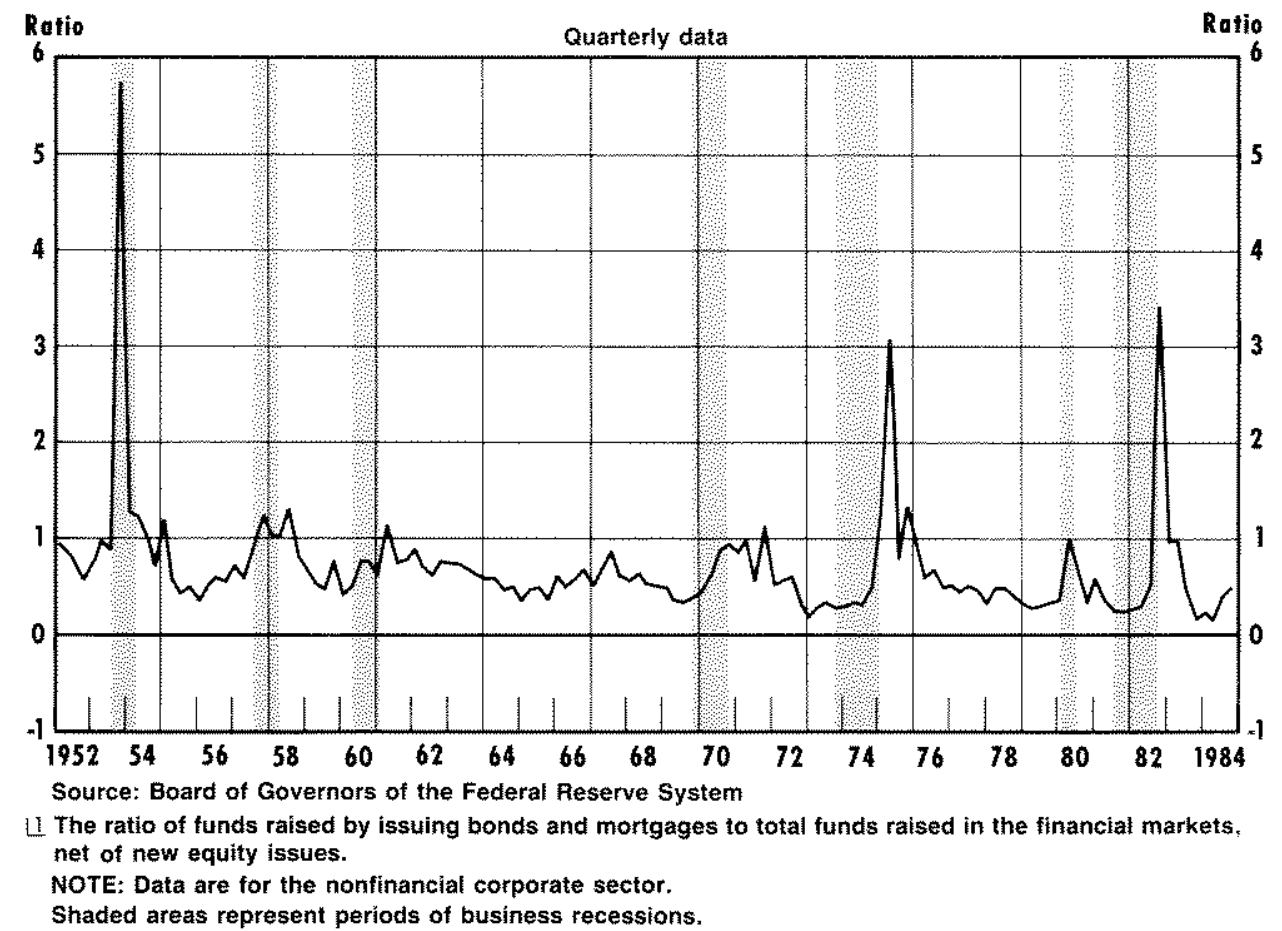

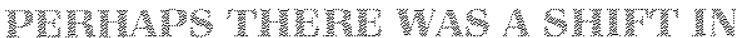

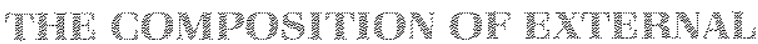

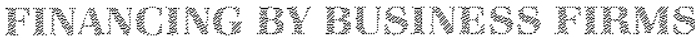

The previous section indicates that the rapid rise in business loans at large banks last year did not reflect an unusually rapid rise in the demand for external financing by business firms. The unusual pattern of business loans at latge banks, therefore, must reflect an unusual change in the composition of external financing by business firms. This section considers various possible changes in the composition of business finance that might account for the rise in business loans at large banks.

\section{A S M

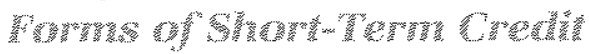

One possible shift may have involved an unusually large reduction in short-term borrowing by businesses from sources other than commercial banks. This possibility is investigated by examining the patterns of commercial paper outstanding issued by nonfinancial firms in the current and previous economic expansions. Chart 6 indicates thest rather than declining in the first half of 1984 , the growth of nonfinancial commercial paper during that period was relatively rapid. Thus, the unusually rapid growth of business loans at large banks in $\mathbf{1 9 8 4}$ does not reflect a shift of business credit from this type of short-term credit to loans at large banks.

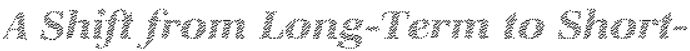

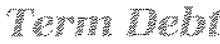

Another possibility is that nonfinancial business corporations reduced their issuance of long-term debt to an unusually large degree in the frrst half of 1984 , substituting short-term for long-term debt as a source of funds. Chart 7 presents the ratio of funds raised by nonfinancial firms by issuing bonds and mortgages to total funds raised through borrowing. This ratio has fallen during the current economic expansion, but its decline is similar to the declines in past expansion periods. Consequently, the unusually rapid growth of business loans at large banks does not appear to be the result of an unusual change in the composition of short-term and long-term debt as sources of funds for nonfinancial business corporations. 
Chart 8

Ratio of Net New Equity Issues to Net Funds Raised

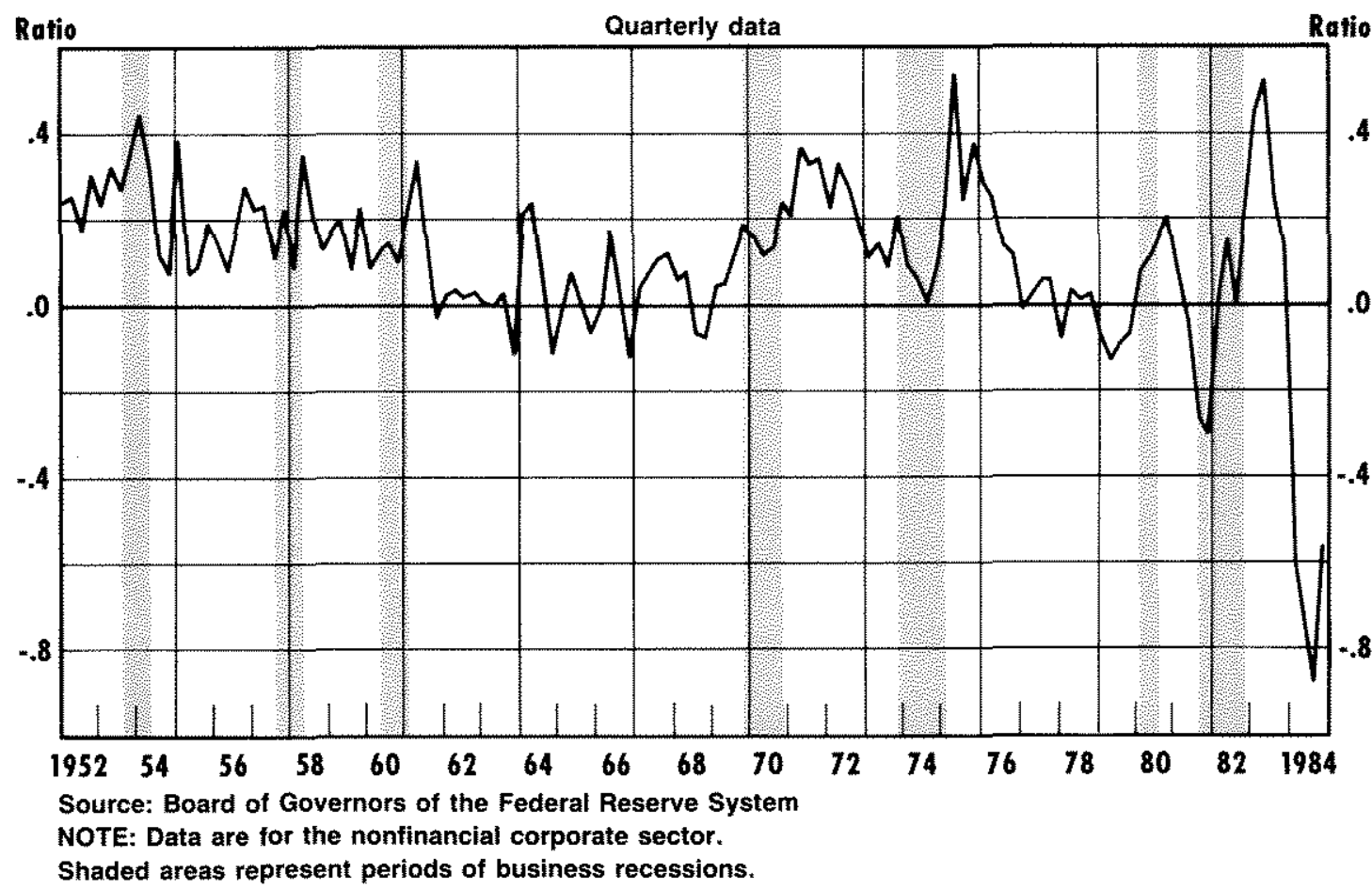

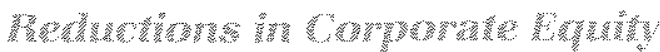

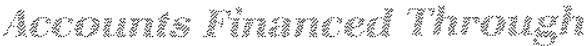

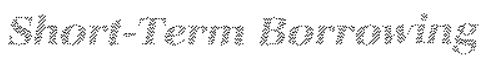

One feature of business finance that does stand out as unusual in the current expansion is the large negam tive values for the net funds raised by nonfinancial firms through equity issues (chart 8 ). A negative value implies that the transactions that reduced the equity capital accounts on the balance sheets of some pub licly held corporations were larger than the funds raised by other such corporations through new equity issues. The net reductions in equity of the nonfinancial corporate sector as a result of financial transactions in each of the first three quarters of 1984 were the largest quarterly reductions ever in the flow of funds data series. These quarterly data are available from 1952. The contemporaneous, rapid rise in business loans at large banks suggests that nonfinancial corporations financed at least part of the transactions in volved in reducing their equity accounts through loans from large banks.

Types of financial transactions that reduce corporate equity - One type of transaction that contributes to a negative value for funds raised through net corporate equity issues involves a business buying back shares of its own common stock. Another is corporate equity reductions due to mergers in which the shareholders who sell their shares receive cash." There were some large mergers involving cash payment in 1984. In recent years, leveraged buyouts (LBOs) also have reduced corporate equity capital accounts. In an LBO, an investor or group of investors borrows funds, often from commercial banks, to buy the shares of publicly traded companies and convert them to privately held companies. Total publicly held corporate equity is reduced by the value of the corporation's equity when it is taken private. A list of large LBOs leach of value over $\$ 10$ million/ tabulated by an industry source indicates that investors borrowed $\$ 13.5$ billion to finance LBOS

\footnotetext{
'For a cash purchase of its own stock, the corporation's assets and equity decline by the same amount. In the case of a purchase of its own stock financed by borrowings, the debt liability rises by the same amount as equity declines. When a merger is effected by one corporation buying another with cash, the equity of the surviving corporation will be the same as before the merger. Thus, aggregate corporate equity is reduced by mergers effected through cash payments to shareholders of the corporations being purchased.
} 


\section{Chart 9 \\ Stock Retirements and the Change in Business Loans at Large Commercial Banks}

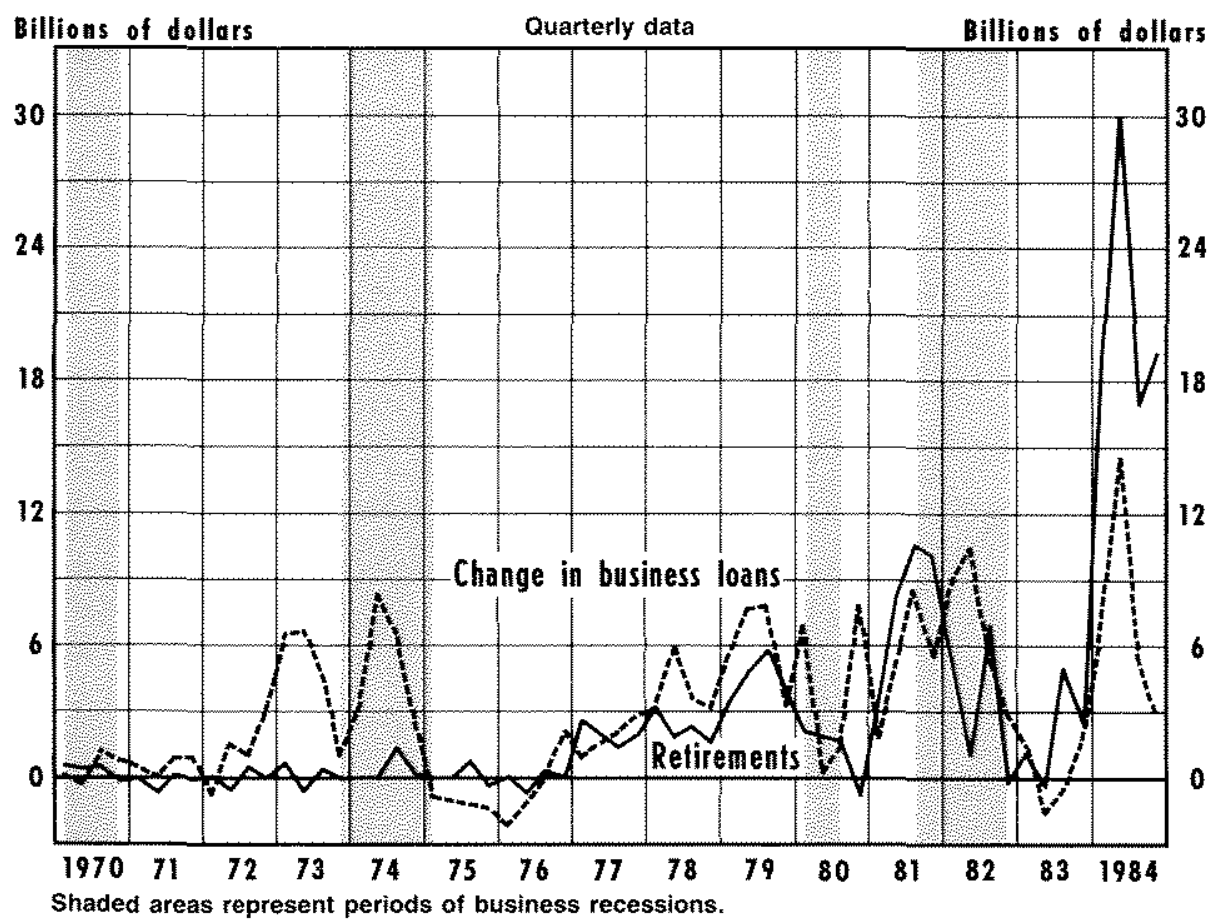

in 1984, up from $\$ 3.2$ billion in 1982 and $\$ 2.8$ billion in 1983.

The negative values for net funds raised through issuing equities reflect transactions that reduce publicly held corporate equity. The magnitude of these transactions can be measured by developing a series of stock retirements. Retirements are reductions in corporate equity claims held by the public as a result of (1) repurchases of their own shares by corporations, (2) mergers transacted as cash purchases and (3) LBOs. Retirements are computed as the difference between the total funds raised by corporations through the sale of new shares minus the net funds raised through equity issues. The net funds raised reflect the retirements of equity as a deduction. As shown in chart 9 ,

${ }^{5}$ The series on stock retirements should be considered an approximation, rather than a census of retirements at all firms. The retirements series is negative in some quarters because of differences in the transactions covered in the series on total funds raised by nonfinancial corporations through the sale of new shares and in the series on net funds raised through equity issues. The series on net funds raised includes estimates of dividend reinvestments and conversions of debt to equity, which are not reflected in the series on funds raised through new equity issues. The series on retirements has a downward bias because of these differences in its components. equity retirements by nonfinancial corporations rose substantially in 1984 relative to the past.

Magnitudes of Equity Retirements and Changes in Short-Term Debt - The timing of the equity retirements shown in chart 9 , as well as their cumulative magnitude, matches up with the anomalous behavior of business loans by large banks shown in chart 1 . The magnitude of the run-up in these loans during the first three quarters of 1984 - over $\$ 26.5$ billion $-m$ is about 40 percent of the total value of equity retirements in this period, $\$ 65.7$ billion. Indeed, the largest quarter of equity retirements was the second quarter, $\$ 30.2$ billion, which was also the largest loan deviation from the past pattem - a rise of $\$ 14,5$ billion in business loans compared with the average of $\$ 2.5$ billion during previous expansions.

'Financing stock retirements is only one reason why businesses borrow from commercial banks. Chart 9 indicates that, from 1970 through about 1976 , there was no relationship between the patterns of stock retirements and changes in business loans. The major reason for the pattern of changes in business loans during that period appears to be inventory investment financed through bank loans. Businesses increased their inventories substantialy in 1973 and 1974 , then gradually reduced them during 1975 and 1976 . For an analysis of the determinants of business loan demand during that period, see Gilbert (1976). 


\section{OMN}

Business loans of large commercial banks followed the usual cyclical pattern during the first year of the current economic expansion. They remained at about the same level as at the trough of the prior recession. During the first half of 1984 , however business loans of large commercial banks rose at rates exceeding those of comparable periods of previous economic expansions, before resuming normal growth in the second half of 1984

The unusually rapid rise in business loans at large commercial banks in the first half of last year does not reflect an unusual rise in business demand for external fnancing. The rise in the pace of economic activity and the requirements of business firms for external financing in the current expansion have been similar to pattems in previous expansions. The most important factor that accounts for the unusually rapid growth of business loans in the first half of 1984 is the increase in corporate mergers and leveraged buyouts financed with loans from large banks. Thus, our analy sis of the pattern of business loans in the current economic expansion indicates that the growth rate of business loans can be an unreliable indicator of the pace of economic activity, since it can be influenced substantially by changes in the composition of external financing by business firms.

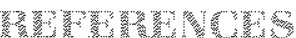

Berry, John M. "Money Supply Figures on Target," Washington Post, July 13, 1984.

"Do Mega-Mergers Drive Up Interest Rates?" Business Week (April 16, 1984), pp. 176-80

Gilbert, R. Alton. "Bank Financing of the Recovery," this Review (July 1976), pp. 2-9.

Giordano, Robert M. "Financial Market Perspectives: Look Before Your Leap," Economic Research, Goldman Sachs Financial Mar" ket Research (July 1984).

Heinemann, Sally. "Fixed Income Markets Still Stabilizing." New York Journal of Commerce (June 18, 1984).

Hicks, Sydney Smith. "Commercial Banks and Business Loan Behavior, "Joumal of Banking and Finance (June 1980), pp. 125-41.

Jasinowski, Jerry J. "Less Stockpiling, More Stability," New York Times, Jure 17, 1984.

Weiner, Lisabeth. "Banks Lag Behind as Business Borrowing Booms," American Banker (August 22, 1984). 